\title{
PENGARUH DEBT TO EQUITY RATIO TERHADAP DIVIDEND PAYOUT RATIO MELALUI RETURN ON ASSET
}

\author{
Rahmat Agus Santoso ${ }^{1}$, Anita Handayani \\ Program Studi Manajemen, Fakultas Ekonomi Dan Bisnis \\ Universitas Muhammadiyah Gresik, Jawa Timur, Indonesia \\ ${ }^{1}$ ra_santoso@umg.ac.id, ${ }^{2}$ anita.handayani@umg.ac.id
}

\begin{abstract}
Dividend distribution becomes a complicated problem due to differences in interests between management and shareholders. Dividends are part of the profits obtained by the company during its business which are distributed to shareholders. The dividend payout ratio determines the amount of profit divided into cash dividends and retained earnings. If the retained earnings of the company are large, the profit to be paid as a dividend will be smaller. Important aspect of dividend policy is determining the appropriate profit allocation between payment of earnings as retained earnings and earnings as dividends. Analysis of the data used in this study uses Partial Least Square (PLS). Debt to Equity Ratio (DER) has a significant negative effect on Return on Assets (ROA). Debt to Equity Ratio (DER) does not directly influence Dividend Payout Ratio (DPR). Return on Assets (ROA) has a significant positive effect on Dividend Payout Ratio (DPR). Return on Assets (ROA) is not able to mediate between Debt to Equity (DER) with Dividend Payout Ratio (DPR).
\end{abstract}

Keywords: Debt to Equity Ratio, Return on Assets, Dividend Payout Ratio

\section{ABSTRAK}

Pembagian dividen menjadi permasalahan yang rumit dikarenakan terjadinya perbedaan kepentingan antara manajemen perusahaan dan pemegang saham. Dividen merupakan bagian keuntungan yang diperoleh perusahaan selama usahanya yang dibagikan kepada para pemegang saham. Rasio pembayaran dividen menentukan jumlah laba dibagi dalam bentuk dividen kas dan laba ditahan. Apabila laba perusahaan yang ditahan dalam jumlah besar, maka laba yang akan dibayarkan sebagai dividen menjadi lebih kecil. Dengan demikian, aspek penting dari kebijakan dividen adalah menentukan alokasi laba yang sesuai diantara pembayaran laba sebagai laba ditahan dengan laba sebagai dividen. Analisis data yang digunakan dalam penelitian ini menggunakan Partial Least Square (PLS). Debt to Equity Ratio (DER) berpengaruh negatif signifikan terhadap Return On Asset (ROA). Debt to Equity Ratio (DER) tidak berpengaruh secara langsung terhadap Dividend Payout Ratio (DPR). Return On Asset (ROA) berpengaruh positif signifikan terhadap Dividend Payout Ratio (DPR). Return On Asset (ROA) tidak mampu memediasi antara Debt to Equity (DER) dengan Dividend Payout Ratio (DPR).

Kata Kunci : Kebijakan Deviden, Return On Asset, Debt to Equity Ratio, Dividend Payout Ratio 


\section{PENDAHULUAN}

Kebijakan dividen merupakan suatu keputusan perusahaan menentukan laba yang telah diperoleh dari hasil usahanya akan diinvestasikan kembali ke perusahaan sebagai laba ditahan atau dibagikan kepada investor dalam bentuk dividen. Mengenai kebijakan dividen, para investor menggunakan informasi tersebutdalam mengambil keputusan. Investor akan memutuskan untuk berinvestasi pada perusahaan yang menetapkan kebijakan dividen tinggi karena dianggap memiliki prospek yang baik di masa mendatang.

Kebijakan dividen merupakan isu penting dalam sebuah perusahaan yang penetapannya harus seimbang dan memperhatikan kepentingan pihakpihak yang berkepentingan terhadap perusahaan. Keputusan perusahaan dalam pembagian dividen dihadapkan oleh beberapa macam pertimbangan, antara lain likuiditas perusahaan, laba ditahan untuk investasi kembali yang lebih menguntungkan, target tertentu berhubungan dengan rasio pembayaran dividen, sifat pemegang saham, serta faktor lain yang berhubungan dengan kebijakan dividen. Maka penting bagi manajer keuangan dalam mengetahui faktor yang mempengaruhi kebijakan dividen yang nantinya menunjukkan kualitas perusahaan sehingga investor tertarik untuk berinvestasi.

Pengambilan keputusan untuk membagikan laba sebagai dividen kepada investor, perusahaan juga dianggap memiliki kinerja yang baik karena diasumsikan mampu membukukan laba dan memperhatikan para investornya. Namun, pembagian dividen menjadi permasalahan rumit dikarenakan terjadinya perbedaan kepentingan antara manajemen perusahaan dan pemegang saham yang disebut dengan masalah keagenan. Karena investor atau pemegang saham lebih menyukai dividen perusahaan dibagikan, namun disisi lain manajemen perusahaan lebih tertarik menggunakan laba yang diperoleh sebagai laba ditahan untuk menambah modal pembiayaan investasi kembali di masa mendatang. Permasalahan penentuan kebijakan dividen. Besar kecilnya dividen yang dibagikan kepada pemegang saham tergantung pada masing-masing kebijakan dividen perusahaan dan kemampuan perusahaan dalam mengahasilkan laba.

Dalam penelitian ini, kebijakan dividen diukur dengan Dividend Payout Ratio (DPR) yaitu presentase laba yang dibagikan dalam bentuk dividen tunai kepada pemegang saham. Besar kecilnya dividend payout ratio akan mempengaruhi keputusan investasi pemegang saham dan berpengaruh pada kondisi keuangan perusahaan. Dividend Payout Ratio (DPR) pada perusahaan di Bursa Efek Indonesia (BEI) tahun 2015-2017 terjadi fluktuatif yang disajikan dalam Gambar berikut ini:

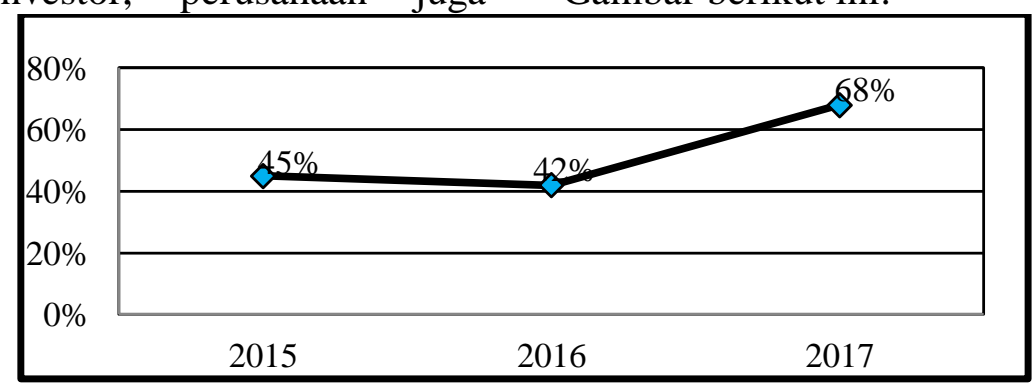

Sumber: Data Diolah Peneliti, 2018

Gambar Rata-Rata Dividend Payout Ratio 
Gambar diatas menunjukkan bahwa pembagian dividen yang didapatkan para pemegang saham pada perusahaan di Bursa Efek Indonesia periode 2015-2017 mengalami fluktuatif. Menurut Hanafi (2008:375) beberapa faktor yang memengaruhi kebijakan dividen yaitu return on asset, current ratio, total asset turnover, firm size, dan debt to equity ratio. Sesuai dengan teori signaling hypothesis, Modigliani dan Miller berpendapat bahwa penurunan dividen diyakini para investor sebagai sinyal bahwa perusahaan menghadapi masa sulit di waktu akan datang (Fahmi, 2014:21).
Profitabilitas merupakan rasio mengukur kemampuan perusahaan dalam menghasilkan laba (Sudana, 2011:22) . Dalam penelitian ini rasio profitabilitas diukur menggunakan Return On Asset (ROA) yang menunjukkan kemampuan perusahaan dalam memperoleh laba bersih dengan diukur dari nilai asetnya (Hanafi dan Halim, 2014: 81-82).. Profitabilitas yang ditunjukkan dengan return on asset pada perusahaan di Bursa Efek Indonesia (BEI) mengalami fluktuatif yang disajikan dalam Gambar berikut :

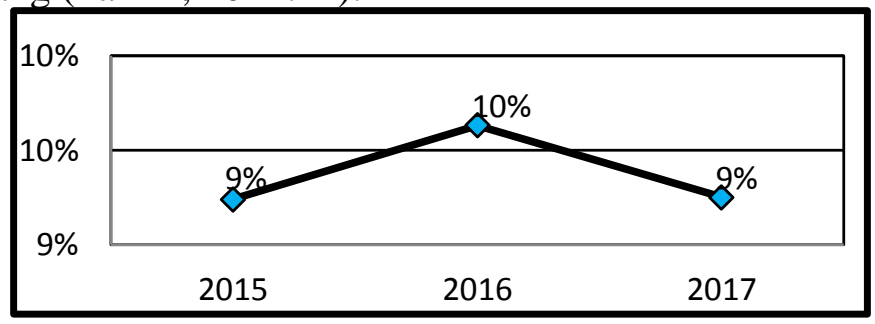

Sumber: Data Diolah Peneliti, 2018

Gambar Rata-Rata Return On Asset

Gambar diatas menunjukkan Debt to Equity Ratio (DER) yaitu profitabilitas yang diproksikan dengan untuk mengukur seberapa besar return on asset perusahaan di Bursa perusahaan dibiayai oleh pihak kreditur Efek Indonesia tahun 2015-2017 dibandingkan dengan modal sendiri. mengalami fluktuatif. Hal ini Penggunaan hutang sebagai sumber menandakan apabila profitabilitas pendanaan akan memberikan beban meningkat maka dividen yang perusahaan dalam menanggung dibagikan juga meningkat (Sartono, pembayaran bunga dan pokok 2010:122). Namun, grafik dividen pinjaman, sehingga semakin tinggi berbanding terbalik dengan grafik Debt to Equity Ratio (DER) maka profitabilitas yaitu ketika dividen semakin kecil dividen yang dibagikan meningkat maka profitabilitas terhadap pemegang saham karena lebih perusahaan menurun dan sebaliknya.

Faktor lain yang harus dipertimbangkan perusahaan dalam menetapkan besarnya membayar dividen adalah tingkat rasio leverage yaitu seberapa besar aktiva perusahaan dibiayai oleh hutang (Fahmi, 2014:75). Rasio leverage diukur menggunakan mengutamakan membayar kewajiban daripada pembagian dividen (Sartono, 2014:66). Leverage ditunjukkan dengan Debt to Equity Ratio (DER) pada perusahaan di Bursa Efek Indonesia (BEI) mengalami penurunan disajikan dalam Gambar berikut: 


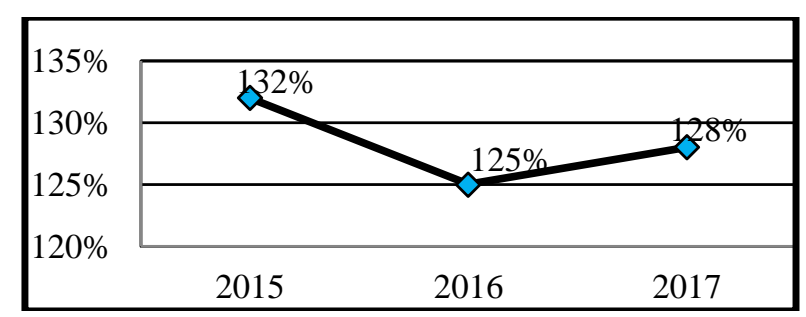

Sumber: Data Diolah Peneliti, 2018

Gambar Rata-Rata Debt to Equity Ratio

Gambar diatas menunjukkan leverage yang diproksikan dengan debt to equity ratio perusahaan di Bursa Efek Indonesia (BEI) tahun 2015-2016 mengalami fluktuatif. Hal ini menandakan apabila leverage perusahaan menurun maka dividen yang dibagikan kepada investor semakin tinggi, dan sebaliknya (Horne dan Wachowicz, 2013:213). Namun, grafik dividen menunjukkan penurunan pada tahun 2015-2016 meskipun tingkat leverage perusahaan mengalami penurunan dan grafik dividen menunjukkan peningkatan pada tahun 2016-2017 meskipun tingkat leverage perusahaan mengalami peningkatan.

Terdapat hasil dari beberapa penelitian terdahulu, antara lain penelitian yang dilakukan Prasetyo (2017) menunjukkan bahwa debt to equity ratio tidak berpengaruh terhadap dividend payout ratio sedangkan return on asset berpengaruh positif signifikan terhadap dividend payout ratio. Namun berbeda dengan penelitian yang dilakukan oleh Mudzakar (2017) menunjukkan bahwa rasio profitabilitas yang diproksikan dengan return on asset tidak berpengaruh terhadap dividend payout ratio.

Hasil penelitian Perpatih (2016) menunjukkan variabel debt to equity ratiodan return on assetberpengaruh positif signifikan terhadap dividend payout ratio. Nurpadilah (2016) juga menyatakan bahwareturn on asset berpengaruh positif signifikan dan debt to equity ratio berpengaruh signifikan terhadap dividend payout ratio tetapi dengan arah negatif. Namun, pada penelitian Prasetyo (2017) menunjukkan bahwa debt to equity ratio tidak berpengaruh terhadap dividend payout ratio.

Tabel Mapping Research Pengaruh Debt to Equity Ratio dan Return On Asset Terhadap Dividend Payout Ratio

\begin{tabular}{|c|c|c|c|c|c|}
\hline Variabel & $\begin{array}{c}\text { Prasetyo } \\
\text { (2017) }\end{array}$ & $\begin{array}{l}\text { Mudzakar } \\
\text { (2017) }\end{array}$ & $\begin{array}{l}\text { Perpatih } \\
\text { (2016) }\end{array}$ & $\begin{array}{l}\text { Nurpadilah } \\
\text { (2016) }\end{array}$ & Research Gap \\
\hline $\begin{array}{l}\text { Debt to Equity } \\
\text { Ratio (DER) }\end{array}$ & $X$ & - & $\sqrt{+}$ & $\sqrt{-}$ & Inkonsistensi \\
\hline $\begin{array}{l}\text { Return On Asset } \\
\text { (ROA) }\end{array}$ & $\sqrt{+}_{+}$ & $\mathrm{X}$ & $\sqrt{+}$ & $\sqrt{+}$ & Inkonsistensi \\
\hline
\end{tabular}

Sumber: Data Diolah Peneliti, 2018

\section{TINJAUN PUSTAKA}

\section{Kebijakan Dividen}

Pembagian dividen menjadi permasalahan yang rumit dikarenakan terjadinya perbedaan kepentingan antara manajemen perusahaan dan pemegang saham. Dividen merupakan bagian keuntungan yang diperoleh perusahaan selama usahanya yang dibagikan kepada para pemegang saham (Rudianto, 2012:290)..

Menurut Martono dan Harjito (2010:253), kebijakan dividen adalah keputusan perusahaan dalam 
mengalokasikan laba yang telah diperolehnya apakah laba yang diperolah akan dibagikan kepada pemegang saham dalam bentuk dividen atau akan ditahan sebagai modal yang digunakan untuk pembiayaan investasi masa mendatang. Apabila perusahaan memutuskan membagi laba sebagai dividen maka akan mengurangi sumber dana dari keuntungan perusahaan. Namun, apabila perusahaan tidak membagikan keuntungannya sebagai dividen, maka dapat memperbesar sumber dana internal yang dapat meningkatkan kemampuan perusahaan dalam mengembangkan perusahaan (Sutrisno, 2012:267).

Rasio pembayaran dividen menentukan jumlah laba dibagi dalam bentuk dividen kas dan laba ditahan. Apabila laba ditahan dalam jumlah besar, maka laba yang dibayarkan sebagai dividen menjadi lebih kecil. Maka aspek penting dari kebijakan dividen adalah menentukan alokasi laba yang sesuai diantara pembayaran laba sebagai laba ditahan dengan laba sebagai dividen.

\section{Dividend Payout Ratio (DPR)}

Menurut Sudana (2011:167), rasio pembayaran dividen adalah dividen tunai tahunan yang dibagi dengan laba tahunan, atau dividen per lembar saham dibagi dengan laba per lembar saham. Rasio tersebut menunjukkan persentase laba perusahaan yang dibayarkan kepada pemegang saham secara tunai. Martono dan Harjito (2010:253), rasio pembayaran dividen merupakan rasio yang mengukur perbandingan dividen terhadap laba perusahaan. Dapat diambil kesimpulan bahwa dividend payout ratio merupakan rasio yang membagi dividen perlembar saham dengan laba perlembar saham. Dividen merupakan arus kas keluar sehingga semakin kuat posisi kas perusahaan, akan mempengaruhi besarnya kemampuan perusahaan dalam membayar dividen. DPR diukur dengan rumus:

DPR

$=\frac{\text { Dividend Per Share (DPS) }}{\text { Earning Per Share (EPS) }} \times 100 \%$

\section{Profitabilitas}

Profitabilitas adalah kemampuan perusahaan dalam memperoleh laba atau keuntungan dalam sutau periode tertentu. Profitabilitas menunjukkan ke efektifitasan manajemen suatu perusahaan. Besar kecilnya laba suatu perusahaan tergantung pada efektifitas dan efisiensi penggunaan sumber daya yang sudah tersedia serta pelaksanaan kegiatan operasionalnya. Sutrisno (2012:16) mengatakan bahwa "profitabilitas adalah kemampuan perusahaan untuk menghasilkan profit atau laba dengan semua modal yang ada di dalam perusahaan tersebut". Profitabilitas diukur dengan:

$$
\mathrm{ROA}=\frac{\text { Laba Bersih }}{\text { Total Aset }} \times 100 \%
$$

\section{Leverage}

Menurut Kasmir (2014:151) rasio solvabilitas atau leverage ratio merupakan rasio yang digunakan untuk mengukur sejauh mana ekuitas perusahaan dibiayai dengan utang. Artinya seberapa besar beban utang ditanggung perusahaan dibandingkan dengan ekuitasnya. Dalam arti luas dikatakan bahwa rasio ini digunakan untuk mengukur kemampuan perusahaan dalam membayar seluruh kewajibannya baik jangka pendek maupun jangka panjang apabila perusahaan dibubarkan. Dalam penelitian ini leverage ratio diproksikan dengan Debt to Equity Ratio (DER). DER diukur dengan:

$$
\text { DER }=\frac{\text { Total Hutang }}{\text { Modal }} \times 100 \%
$$




\section{Hubungan Debt to Equity Ratio (DER) dengan Return On Asset (ROA) \\ Debt to equity ratio menunjukkan seberapa besar perusahaan dibiayai oleh pihak kreditur dibanding dengan modal sendiri (Kasmir, 2014:155). Rasio leverage memiliki pengaruh terhadap profitabilitas. Apabila rasio hutang semakin besar dibandingkan modal sendiri, maka akan berdampak pada profitabilitas perusahaan karena sebagian laba akan digunakan untuk membayar pinjaman perusahaan. Hasil penelitian Oktary (2017), serta Dewi, Cipta, dan Kirya (2015) menyatakan bahwa debt to equity ratio memiliki pengaruh negatif signifikan terhadap return on asset.}

\section{Hubungan Debt to Equity Ratio (DER) dengan Dividend Payout Ratio (DPR)}

Debt to equity ratio yakni rasio untuk mengukur utang atau dana dari luar perusahaan terhadap modal sendiri. Semakin besar rasio hutang, akan menunjukkan semakin besar juga tingkat ketergantungan perusahaan terhadap pihak kreditur sehingga semakin besar beban biaya hutang yang harus dibayar perusahaan. Hal tersebut akan berdampak terhadap penurunan laba yang diperoleh perusahaan karena sebagian dialokasikan untuk membayar hutang atau bunga pinjaman (Hardinugroho,2012). Dengan hutang meningkat, maka kemampuan perusahaan dalam membayar dividen kepada investor semakin rendah. Dapat disimpulkan bahwa debt to equity ratio berpengaruh signifikan terhadap dividend payout ratio. Pada hasil penelitian Akmal, Zainudin, dan Yulianti (2016), Hayati dan Norbaiti (2016), Hendra (2017) menyatakan bahwa debt to equity ratio berpengaruh negatif signifikan terhadap dividend payout ratio.

Hubungan Return On Asset (ROA) dengan Dividend Payout Ratio (DPR) Return on asset merupakan pengukuran kemampuan perusahaan mengasilkan laba dengan menggunakan aktiva yang dimiliki (Sudana, 2011:22). Semakin besar tingkat rasio return on asset menunjukkan kemampuan tingginya perolehan laba perusahaan dan kinerja perusahaan yang baik sehingga tingkat pengembalian (return) yang diharapkan juga semakin besar. Tingkat pengembalian tersebut dapat berupa dividen yang akan dibagikan kepada pemegang saham. Dapat disimpulkan bahwa ketika laba yang dihasilkan perusahaan tinggi, maka dividen yang akan dibagikan juga semakin tinggi (Haryetti dan Ekayanti, 2012). Hal tersebut didukung dengan penelitian Mubarok (2016), Akmal, Zainudin, dan Yulianti (2016) menyatakan bahwa return on asset bepengaruh signifikan terhadap dividend payout ratio.

\section{Hubungan Debt to Equity Ratio (DER) dengan Dividend Payout Ratio (DPR) Melalui Return On Asset (ROA)}

Debt to equity ratio menunjukkan seberapa besar perusahaan dibiayai oleh pihak kreditur dibandingkan dengan modal sendiri (Kasmir, 2014:155). Apabila hutang perusahaan tinggi, maka laba diperoleh perusahaan dialokasikan untuk membayar hutang perusahaan. Dengan meningkatnya hutang, maka kemampuan perusahaan dalam membayar dividen kepada investor akan semakin rendah (Hardinugroho,2012). Dapat disimpulkan apabila perusahaan memiliki hutang yang tinggi, maka dividen yang akan dibagikan kepada pemegang saham semakin rendah. 


\section{Hipotesis}

H1 : Debt to Equity Ratio (DER) berpengaruh langsung terhadap Return On Asset (ROA) pada perusahaan di Bursa Efek Indonesia (BEI) tahun 2015-2017

$\mathrm{H} 2$ : Debt to Equity Ratio (DER) berpengaruh langsung terhadap Dividend Payout Ratio (DPR) pada perusahaan di Bursa Efek Indonesia (BEI) tahun 2015-2017

H3 : Return On Asset (ROA) berpengaruh langsung terhadap Dividend Payout Ratio (DPR) pada perusahaan di Bursa Efek Indonesia (BEI) tahun 2015-2017

H4 : Debt To Equity Ratio (DER) berpengaruh secara tidak langsung terhadap Dividend Payout Ratio (DPR) melalui Return On Asset (ROA) pada perusahaan di Bursa Efek Indonesia (BEI) tahun 2015-2017

\section{Kerangka Konseptual}

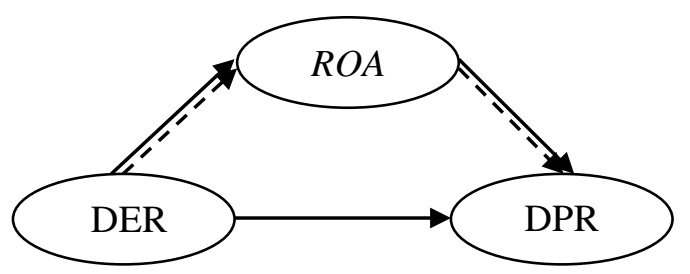

Gambar Kerangka Konseptual

\section{METODE PENELITIAN}

Pendekatan Penelitian

Pendekatan yang digunakan adalah pendekatan kuantitatif bertujuan untuk menguji hipotesis. Analisis data yang digunakan statistik inferensial yaitu metode statistika yang digunakan untuk mengetahui tentang sebuah populasi berdasarkan sampel (Martiningtyas, 2011:1). Penelitian ini bersifat deduktif dilakukan untuk menguji hipotesis berlandaskan teori (Asnawi dan Masyhuri, 2011:20).

Penelitian menggunakan data panel yaitu kombinasi antara data silang tempat (cross section) dengan data runtut waktu (time series) (Gujarati dan Porter, 2009:237). Populasinya adalah perusahaan yang tercatat pada Bursa Efek Indonesia yang menerbitkan laporan keuangan secara tepat waktu. Sampel memiliki kriteria sebagai berikut: semua perusahaan di Bursa Efek Indonesia yang menerbitkan laporan keuangan secara tepat waktu, memiliki laba dan membagikan dividen secara berturutturut selama tiga tahun yaitu 20152017. Berdasarkan kriteria tersebut diperoleh sebanyak 40 perusahaan. Penelitian ini dilakukan dengan tiga kali observasi yaitu tahun 2015 sampai dengan tahun 2017. Sehingga jumlah perusahaan yang diamati sebanyak 120 data perusahaan. Jenis data yang digunakan dalam penelitian ini adalah data dokumenter yaitu data berupa laporan keuangan perusahaan terdaftar di Bursa Efek Indonesia pada tahun 2015-2017. Sumber data dalam penelitian ini adalah data sekunder yang diolah yaitu meliputi ikhtisar data keuangan yang terdapat pada annual report tahun 2015-2017 pada perusahaan Bursa Efek Indonesia .

\section{Teknik Analisis Data}

Analisis data yang digunakan adalah Partial Least Square (PLS). Teknik analisis multivariate menggabungkan antara regresi dan analisis faktor (Sholihin dan Ratmono, 2013:8). Dari analisis data tersebut menghasilkan persamaan yaitu:

1. $Z=\beta X+$ e........ (Persamaan $I)$

2. $Y=\beta X+\beta Z+\beta X . \beta Z+$ e..(Persamaan II)

Keterangan :

$\mathrm{Z}=$ Variabel Intervening (ROA)

$\mathrm{Y}=$ Variabel Endogen/Dependen(DPR)

$\beta=$ KoefisienVariabel

$\mathrm{X}=$ Debt to Equity Ratio (DER)

$\mathrm{e}=$ error 


\section{Uji Kelayakan Model}

$\mathrm{R}$-square model partial least square dapat dilihat dengan Q-square predictive relevance untuk model variabel. Q-square digunakan untuk mengukur baiknya nilai observasi yang dihasilkan model beserta estimasi parameternya. Apabila nilai $\mathrm{Q}^{2} \geq 0$, nilai model bermakna predictive relevance, $\mathrm{Q}^{2} \leq 0$ maka nilai model kurang predictive relevance. Maka persamaannya adalah sebagai berikut: $\mathrm{Q}^{2}=1-\left(1-\mathrm{R}_{1}^{2}\right)\left(1-\mathrm{R}_{2}^{2}\right) \ldots\left(1-\mathrm{R}_{\mathrm{p}}^{2}\right)$

Selain itu, untuk menguji goodness of fit dapat ditentukan dengan menampilkan 3 indikator fit yaitu Average Path Coefficient (APC), Average $R$-Squared (ARS), dan Average Variance Inflation Factor (AVIF) yang harus terpenuhi. Untuk nilai $p$-value Average Path Coefficient (APC) dan Average R-Squared (ARS) harus lebih kecil dari 0,05 atau berarti signifikan. Selain itu, nilai Average Variance Inflation Factor (AVIF) harus lebih kecil dari 5 (Sholihin dan Ratmono, 2013:61).

\section{Uji Hipotesis}

Untuk mengukur atau menjelaskan arah hubungan antar variabel atau model serta menjelaskan hipotesis dalam penelitian ini dapat dilakukan dengan melihat nilai $p$-value dalam memprediksi direct effect dan uji sobel untuk memprediksi indirect effect. (Ghozali, 2016)

\section{Analisis Data}

Teknik analisis data yang digunakan dalam penelitian ini adalah Partial Least Square (PLS) dengan Dividend Payout Ratio (DPR) sebagai variabel endogen (Y), Debt to Equity Ratio (DER), dan Return On Asset (ROA) sebagai variabel mediasi $(\mathrm{Z})$. Analisis ini digunakan untuk mengetahui pengaruh debt to equity ratio terhadap dividend payout ratio melalui return on asset pada perusahaan di Bursa Efek Indonesia tahun 2015-2017. Hasil analisis diperoleh dengan menggunakan warpPLS 5.0.

Dalam penelitian ini terdapat pengujian effect mediasi yang menunjukkan estimasi direct effect dan indirect effect. Direct effect pada penelitian ini adalah menunjukkan pengaruh debt to equity ratio terhadap return on asset, debt to equity ratio dan return on asset terhadap dividend payout ratio. sedangkan indirect effect pada penelitian ini menunjukkan pengaruh debt to equity ratio terhadap dividend payout ratio melalui return on asset. Berikut hasil pengujian direct effect dan indirect effect:

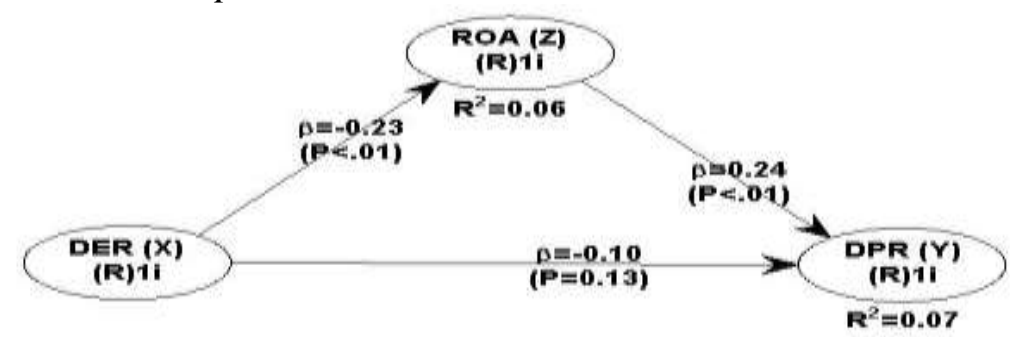

Gambar Direct Effect dan Indirect Effect

Hasil pengujian direct effect dan indirect effect diatas menghasilkan dua

(2) persamaan yaitu sebagai berikut: $\mathrm{Z}=\beta \mathrm{X}+\mathrm{e}$.........(Persamaan I) $\mathrm{Z}=-0,23 \mathrm{X}+\mathrm{e} \ldots \ldots \ldots($ Persamaan $\mathrm{I})$
Dari persamaan I, dapat menghasilkan kesimpulan bahwa nilai koefisien DER adalah sebesar $-0,23$ yang menunjukkan jika DER (X) berubah, maka variabel ROA (Z) akan turun sebesar 0,23. Nilai koefisien DER (X) 
memiliki nilai yang negatif terhadap ROA (Z) yang artinya jika nilai DER meningkat, maka nilai ROA suatu perusahaan cenderung menurun.

$\mathrm{Y}=\beta \mathrm{X}+\beta \mathrm{Z}+\beta \mathrm{X} . \beta \mathrm{Z}+\mathrm{e} \ldots$..(Persamaan II) $Y=-0,10 X+0,24 Z-0,23 X \cdot 0,24 Z+$ e........... (Persamaan II)

Dari persamaan II, dapat menghasilkan kesimpulan berikut:

a. Nilai koefisien DER adalah sebesar $-0,10$ yang menunjukkan jika DER (X) berubah, maka variabel DPR (Y) akan turun sebesar 0,10 dengan asumsi bahwa variabel ROA (Z), dan DER (X) yang dimediasi ROA (Z) nilainya tetap. Nilai koefisien DER (X) memiliki nilai yang negatif terhadap DPR (Y) artinya jika nilai DER meningkat, maka nilai DPR suatu perusahaan akan menurun.

b. Nilai koefisien ROA adalah sebesar 0,24 yang menunjukkan jika ROA (Z) berubah, maka variabel DPR (Y) akan naik sebesar 0,24 dengan asumsi bahwa variabel DER (X) dan DER (X) yang dimediasi ROA (Z) nilainya tetap. Nilai koefisien ROA (Z) memiliki nilai yang positif terhadap DPR (Y) artinya jika nilai ROA meningkat, maka nilai DPR suatu perusahaan juga meningkat.

c. Nilai koefisien DER yang dimediasi oleh ROA adalah sebesar $-0,0552$ yang menunjukkan jika DER (X) yang dimediasi ROA (Z) berubah, maka variabel DPR (Y) akan turun sebesar 0,0552 dengan asumsi bahwa variabel DER (X) dan ROA (Z) nilainya tetap.

d. Nilai $R^{2}$ pada model atau persamaan pertama adalah sebesar 0,06, sedangkan pada persamaan kedua sebesar 0,07. Dapat disimpulkan bahwa dengan adanya Return On Asset (ROA) sebagai variabel mediasi dapat meningkatkan pengaruh debt to equity ratio terhadap dividend payout ratio.

\section{Uji Kelayakan Model}

Model fit indices dan p-value ditentukan dengan menampilkan 3 indikator fit yaitu Average Path Coefficient (APC), Average R-Squared (ARS), dan Average Variance Inflation Factor (AVIF) yang harus terpenuhi. Untuk nilai $p$-value Average Path Coefficient (APC) dan Average $R$ Squared (ARS) harus lebih kecil dari 0,05 atau berarti signifikan. Selain itu, nilai Average Variance Inflation Factor (AVIF) harus lebih kecil dari 5. Hasil estimasi direct effect dan indirect effect koefisien Average Path Coefficient (APC) sebesar 0,193 dan mempunyai nilai $p$-value sebesar 0,007 yang berarti signifikan. Koefisien Average R-Squared (ARS) pada hasil estimasi direct effect dan indirect effect juga signifikan dengan koefisien sebesar 0,061 dan p-value 0,025. Indikator fit yang terakhir adalah Average Variance Inflation Factor (AVIF) dengan koefisien sebesar 1,005. Hasil tersebut menunjukkan kriteria goodness of fit telah terpenuhi yaitu nilai Average Path Coefficient (APC) dan Average R-Squared (ARS) signifikan dan Average Variance Inflation Factor (AVIF) memiliki nilai koefisien kurang dari 5. Hal ini menunjukkan bahwa persyaratan untuk pengujian model mediasi diterima.

Pengujian kelayakan model atau $\mathrm{R}$-square model partial least square juga dapat dilihat dengan Q-square predictive relevance untuk model variabel Q-square digunakan untuk mengukur baiknya nilai observasi yang dihasilkan model. Apabila nilai $\mathrm{Q}^{2} \geq 0$, nilai model bermakna predictive relevance, $\mathrm{Q}^{2} \leq 0$ maka nilai model kurang predictive relevance. Diketahui $\mathrm{R}_{1}^{2}$ sebesar 0,06 dan $\mathrm{R}_{2}^{2}$ sebesar 0,07, yang dapat dihitung dengan rumus sebagai berikut: 


$$
\begin{aligned}
\mathrm{Q}^{2} & =1-\left(1-\mathrm{R}_{1}^{2}\right)\left(1-\mathrm{R}_{2}^{2}\right) \\
& =1-(1-0,06)(1-0,07) \\
& =1-(0,94 \times 0,93)=1-0,87=\mathbf{0 , 1 3}
\end{aligned}
$$

Berdasarkan hasil perhitungan, diperoleh Q-square sebesar 0,13. Hal ini berarti nilai Q-square lebih besar dari pada 0 (nol) yang bermakna predictive relevance dan menunjukkan kontribusi variabel eksogen (X) yaitu debt to equity ratio terhadap variabel endogen (Y) yaitu dividend payout ratio yang melalui return on asset sebagai variabel mediasi adalah sebesar $13 \%$. Sisanya sebesar $87 \%$ dijelaskan oleh faktor lain yang berada di luar model penelitian ini. Dengan demikian, dari hasil tersebut maka model penelitian ini dapat dinyatakan telah memiliki goodness of fit yang baik.

\section{Uji Hipotesis}

Berdasarkan pengujian analisis jalur dengan menggunakan software warpPLS 5.0, untuk direct effect dilihat dari nilai $p$-value dan indirect effect dilihat dari hasil perhitungan uji sobel. Hasil dari uji hipotesis dalam penelitian ini yaitu pengaruh debt to equity ratio terhadap dividend payout ratio melalui return on asset adalah sebagai berikut:

1. Hasil pengujian menunjukkan bahwa koefisien direct effect DER terhadap ROA adalah sebesar - 0,23 yang artinya variabel DER memiliki hubungan negatif dengan variabel ROA. Nilai signifikansi untuk variabel DER sebesar $0,01<0,05$, hal ini menunjukkan bahwa $\mathrm{H} 1$ diterima. Dengan demikian dapat diartikan bahwa ada pengaruh langsung antara DER dengan ROA.

2. Hasil pengujian menunjukkan bahwa koefisien direct effect DER terhadap DPR adalah sebesar $-0,10$ yang artinya variabel DER memiliki hubungan negatif dengan variabel DPR. Nilai signifikansi untuk variabel DER sebesar 0,13>0,05, hal ini menunjukkan bahwa $\mathrm{H} 2$ ditolak. Dengan demikian dapat diartikan bahwa tidak ada pengaruh langsung antara DER dengan DPR.

3. Hasil pengujian menunjukkan bahwa koefisien direct effect ROA terhadap DPR adalah sebesar 0,24 yang artinya variabel ROA memiliki hubungan positif dengan variabel DPR. Nilai signifikansi untuk variabel ROA sebesar $0,01<0,05$, hal ini menunjukkan bahwa $\mathrm{H} 3$ diterima. Dengan demikian dapat diartikan bahwa ada pengaruh langsung antara ROA dengan DPR

4. $\mathrm{DER} \longrightarrow \mathrm{ROA}=-0,23$ (a)

$$
\begin{aligned}
& \mathrm{Sa}=0,086(\text { standar } \text { error } \mathrm{a}) \\
& \mathrm{ROA} \longrightarrow \mathrm{DPR}=0,24 \text { (b) } \\
& \mathrm{Sb}=0,086(\text { standar } \text { error } \mathrm{b}) \\
& \mathrm{Sab}=\sqrt{\mathrm{b}^{2} \mathrm{Sa}^{2}+\mathrm{a}^{2} \mathrm{Sb}^{2}+\mathrm{Sa}^{2} \mathrm{Sb}^{2}} \\
& \sqrt{(0,24)^{2} \cdot(0,086)^{2}+(-0,23)^{2} \cdot(0,086)^{2}+(0,086)^{2} \cdot(0,086)^{2}} \\
& \sqrt{(0,0576.0,0074)+(0,0529.0,0074)+(0,0074.0,0074)} \\
& \sqrt{0,000426+0,000391+0,000055} \\
& \sqrt{0,000872}=0,030 \\
& \mathrm{t}=\frac{\mathrm{ab}}{\mathrm{Sab}} \\
& =\frac{-0,23.0,24}{0,030}=\frac{-0,0552}{0,030}=-1,84 \\
& \text { Berdasarkan perhitungan diatas, } \\
& \text { untuk jalur diperoleh nilai t-hitung } \\
& \text { sebesar -1,84 lebih kecil dari t-tabel } \\
& \text { yaitu sebesar } 1,98 . \quad \text { Koefisien } \\
& \text { mediasi antara DER terhadap DPR } \\
& \text { oleh ROA adalah -0,10 }+(-0,0552) \\
& =-0,16, \text { artinya variabel DER yang } \\
& \text { dimediasi ROA memiliki hubungan } \\
& \text { negatif dengan variabel DPR. } \\
& \text { Dengan demikian dapat disimpulkan } \\
& \text { bahwa H4 ditolak yaitu ROA tidak } \\
& \text { mampu menjadi mediasi pengaruh } \\
& \text { antara DER dengan DPR. }
\end{aligned}
$$

\section{HASIL PENELITIAN \\ Debt to Equity Ratio (DER) Terhadap Return On Asset (ROA)}

Hasil pengujian penelitian ini menunjukkan DER memiliki arah 
hubungan yang negatif dan signifikan terhadap Return On Asset (ROA). Sehingga terbukti sesuai dengan hipotesis bahwa DER berpengaruh secara langsung terhadap ROA pada perusahaan yang terdaftar di Bursa Efek Indonesia (BEI) tahun 2015-2017. Arah pengaruh negatif menjelaskan bahwa semakin tinggi nilai debt to equity ratio, maka nilai return on asset perusahaan akan menurun.

Perusahaan dengan proporsi dana eksternal lebih besar dibandingkan dana internal akan mempengaruhi tingkat profitabilitas perusahaan. Penggunaan dana eksternal sebagai biaya operasional akan menyebabkan rasio hutang semakin besar atau biaya pinjaman lebih besar. Hal ini akan menuntut perusahaan untuk membayar biaya pinjaman perusahaan, sehingga tingkat profitabilitas perusahaan cenderung menurun karena digunakan untuk membayar pinjaman. Hasil penelitian ini sesuai dengan Oktary (2017), serta Dewi, Cipta, dan Kirya (2015) menyatakan bahwa debt to equity ratio memiliki pengaruh negatif signifikan terhadap return on asset.

\section{Pengaruh Debt to Equity Ratio (DER) Terhadap Dividend Payout Ratio (DPR)}

Hasil pengujian penelitian ini menunjukkan bahwa) memiliki arah hubungan yang negatif terhadap Dividend Payout Ratio (DPR) dan tidak signifikan. Sehingga tebukti tidak sesuai hipotesis bahwa Debt to Equity Ratio (DER) tidak berpengaruh secara langsung terhadap Dividend Payout Ratio (DPR) pada perusahaan yang terdaftar di Bursa Efek Indonesia (BEI) tahun 2015-2017. Meskipun tidak signifikan, arah pengaruh negatif menjelaskan bahwa semakin besar komposisi utang terhadap modal sendiri, maka dividen yang dibagikan akan menurun. Namun, tidak signifikan dapat disimpulkan bahwa besar kecilnya komposisi hutang terhadap modal senidiri tidak mempengaruhi kebijakan dividen perusahaan.

Gumanti (2013:87) menjelaskan bahwa salah satu faktor yang mempengaruhi kebijakan dividen adalah pengendalian terhadap perusahaan sehingga pemilik tidak ingin kehilangan kendali perusahaan dikarenakan masuknya investor baru yang telah menginvestasikan dananya kepada perusahaan tersebut yang dapat mengurangi kekuasaan mengendalikan perusahaan. Sehingga perusahaan akan mengutamakan untuk membayar hutang dengan keuntungan yang diperoleh dibandingkan membagikan dividen kepada pemegang saham agar pengendalian lebih mayoritas kepada pemilik internal perusahaan. Maka, perusahaan tidak membagikan dividen agar pengendalian tetap berada pada pemilik lama. Hasil penelitian ini sesuai penelitian Muhammadinah dan Jamil (2015:12) yang menyatakan bahwa debt to equity ratio tidak berpengaruh signifikan terhadap dividend payout ratio .

Pengaruh Return On Asset (ROA) Terhadap Dividend Payout Ratio (DPR)

Hasil pengujian penelitian ini menunjukkan bahwa ROA memiliki arah hubungan yang positif dan signifikan terhadap Dividend Payout Ratio (DPR). Sehingga terbukti sesuai dengan hipotesis bahwa ROA berpengaruh secara langsung terhadap Dividend Payout Ratio (DPR) pada perusahaan yang terdaftar di Bursa Efek Indonesia (BEI) tahun 2015-2017. Arah pengaruh positif menjelaskan bahwa semakin besar nilai return on asset perusahaan maka semakin besar juga dividen yang akan dibagikan. 
Tingkat profitabilitas perusahaan berpengaruh terhadap kebijakan dividen suatu perusahaan. Salah satu tujuan perusahaan memaksimalkan kemakmuran pemegang saham sehingga perusahaan dituntut untuk menghasilkan profit yang besar. Perusahaan-perusahaan yang go public menarik investor dengan memberikan return yang tinggi. Jadi, semakin tinggi laba yang dihasilkan oleh perusahaan maka semakin tinggi juga laba yang dibagikan dalam bentuk dividen kepada para pemegang saham. Hasil penelitian ini sesuai dengan Mubarok (2016), Akmal, Zainudin, dan Yulianti (2016) yang menyatakan bahwa return on asset bepengaruh positif signifikan terhadap dividend payout ratio.

\section{Hubungan Debt to Equity Ratio (DER) dengan Dividend Payout Ratio (DPR) Melalui Return On Asset (ROA)}

Hasil pengujian penelitian ini menunjukkan bahwa DER memiliki arah hubungan yang negatif dan tidak signifikan terhadap DPR. Sehingga terbukti tidak sesuai hipotesis bahwa Return On Asset (ROA) tidak mampu memediasi debt to equity ratio terhadap dividend payout ratio.

Adanya perusahaan yang lebih memilih menggunakan dana eksternal dibandingkan dengan dana internal sehingga besar kecilnya hutang akan mempengaruhi tingkat profitabilitas perusahaan. Selain itu, hal ini juga disebabkan karena pemilik tidak ingin kehilangan kendali perusahaan akibat masuknya investor baru yang telah menginvestasikan dananya kepada perusahaan tersebut yang dapat mengurangi kekuasaan untuk mengendalikan perusahaan. Sehingga perusahaan akan mengutamakan untuk membayar hutang dengan keuntungan yang diperoleh dibandingkan membagikan dividen kepada pemagang saham agar pengendalian lebih mayoritas kepada pemilik internal perusahaan. Oleh karena itu, semakin besar biaya pinjaman oleh perusahaan maka laba yang diperoleh akan dialokasikan untuk membayar pinjaman tersebut sehingga dapat memperkecil dividen yang dibagikan kepada pemegang saham.

\section{KESIMPULAN}

1. Debt to Equity Ratio (DER) berpengaruh negatif signifikan terhadap Return On Asset (ROA).

2. Debt to Equity Ratio (DER) tidak berpengaruh secara langsung terhadap Dividend Payout Ratio (DPR).

3. Return On Asset (ROA) berpengaruh positif signifikan terhadap Dividend Payout Ratio (DPR).

4. Return On Asset (ROA) tidak mampu memediasi antara Debt to Equity (DER) dengan Dividend Payout Ratio (DPR).

\section{Rekomendasi}

Berdasarkan kesimpulan, terdapat beberapa rekomendasi sebagai berikut:

1. Bagi perusahaan dengan berdasarkan interpretasi hasil, untuk lebih meminimalkan penggunaan dana eksternal sehingga laba yang diperoleh dapat dibagikan dalam bentuk dividen kepada para pemegang saham dengan nilai yang lebih besar. Hal ini akan menarik investor untuk menanamkan modalnya terhadap perusahaan.

2. Bagi Investor, sebaiknya melakukan analisa terlebih dahulu mengenai kinerja keuangan terhadap perusahaan yang akan dituju dalam melakukan investasi agar investor dapat memilih perusahaan dengan memiliki tingkat profitabilitas yang 
tinggi. Sehingga para investor akan mendapatkan return dari perusahaan sesuai dengan yang diharapkan.

3. Bagi Penelitian Selanjutnya, direkomendasi untuk menambahkan variabel eksogen $(\mathrm{X})$ yang diduga juga berpengaruh terhadap kebijakan dividen seperti Current Ratio (CR) dan Total Asset Turnover (TATO).

\section{DAFTAR PUSTAKA}

Akmal, Zainudin, dan Rahmah Yulianti. 2016. Pengaruh Return On Asset, Sales Growth, Firm Size, dan Debt to Equity Ratio Terhadap Pembayaran Dividen pada Perusahaan Manufaktur Sub Sektor Perusahaan Makanan dan Minuman yang Terdaftar di Bursa Efek Indonesia Periode 20102014. Jurnal Ekonomi Manajemen dan Akuntansi, Vol. 2, No.2, Tahun 2016. ISSN: 24605891 .

Asnawi, Nur dan Masyhuri. 2011. Metodologi Riset Manajemen Pemasaran. Malang: UINMALIKI PRESS.

Dewi, Wayan Cipta, dan Kirya. 2015. Pengaruh LDR, LAR, DER, dan CR Terhadap ROA. E-Journal Bisma Universitas Pendidikan Ganesha, Vol. 3, Tahun 2015.

Fahmi, Irham. 2014. Manajemen Keuangan Perusahaan dan Pasar Modal. Jakarta: Mitra Wacana Media.

Ghozali, Imam. 2016. Aplikasi Analisis Multivariate dengan Program IBM SPSS 23 (ED ke-8). Semarang: Badan Penerbit Universitas Diponegoro.
Gujarati dan Porter. 2009. DasarDasar Ekonometrika. Jakarta: Salemba Empat.

Gumanti, Tatang Ary. 2013. Kebijakan Dividen: Teori, Empiris, dan Implikasi. Edisi Pertama.Yogyakarta: UPP STIM YKPN.

Hanafi, Mamduh. 2008. Manajemen Keuangan. Edisi Kesatu. Yogyakarta: BPFE.

Hanafi, Mamduh M. dan Abdul Halim. 2014. Analisis Laporan Keuangan. Edisi Ketujuh. Yogyakarta: UPP AMP YKPN.

Hardinugroho, Agung. 2012. Analisis Faktor-Faktor yang Memengaruhi Dividend Payout Ratio pada Perusahaan Manufaktur yang Terdaftar di Bursa Efek Indonesia. Semarang, Universitas Diponegoro.

Haryetti dan Ekayanti, R.A. 2012. Pengaruh Profitabilitas, Investment Opportunity Set dan Pertumbuhan

PerusahaanTerhadap Kebijakan Dividen pada Perusahaan LQ-45 yang Terdaftar di Bursa Efek Indonesia. Jurnal Ekonomi, Vol. 20, No. 3, September 2012.

Hayati, Nurul dan Norbaiti. 2016. Pengaruh Cash Potition, Return On Asset, Return On Equity, Debt to Equity Ratio, Current Ratio, Asset Growth Terhadap Dividend Payout Ratio pada Perusahaan Manufaktur Sektor Industri. Jurnal Spread, Vol. 6, No.1, April 2016. 
Hendra, Joni. 2017. Pemgaruh Rasio Keuangan dan Jaminan Aset Terhadap Kebijakan Dividen pada Perusahaan Manufaktur di Bursa Efek Indonesia. Jurnal Ilmiah Ilmu Akuntansi, Keuangan, dan Pajak, Vol. 1, No. 1, Januari 2017.

Horne, Van dan Wachowicz. 2013. Prinsip-Prinsip Manajemen Keuangan. Jakarta: Salemba Empat.

Kasmir. 2014. Analisis Laporan Keuangan. Jakarta: PT Raja Grafindo Persada.

Martiningtyas, Nining. 2011. Teori, Soal dan Pembahasan Statistika. Jakarta: PT. Prestasi Pustakarya.

Martono dan Agus Harjito. 2010. Manajemen Keuangan. Edisi Ketiga. Yogyakarta: Ekonisia.

Mubarok, Nurul. 2016. Pengaruh Current Ratio, Debt to Equity Ratio, Total Asset Turnover dan Return On Asset Terhadap Dividend Payout Ratio pada Perusahaan Sektor Industri Barang Konsumsi yang Terdaftar di Bursa Efek Indonesia. IFinance, Vol. 2, No. 2 Desember 2016.

Mudzakar, Mochamad Kohar. 2017. Analisis Profitabilitas Terhadap Kebijakan Dividen. Converence on Management and Behavioral Studies

Universitas Tarumanagara Jakarta. ISSN: 2541-3406. E-ISSN: 2541-285X.

Muhammadinah dan Mahmud Alfan Jamil. 2015. Pengaruh Current Ratio, Debt to Equity Ratio, Total
Asset Turnover dan Return On Asset Terhadap Dividend Payout Ratio pada Perusahaan Sektor Industri Barang Konsumsi yang Terdaftar di Bursa Efek Indonesia. I-Economics Journal, Vol. 01, No. 01.

Nurpadilah, Itsna. 2016. Pengaruh Profitabilitas dan Leverage Terhadap Kebijakan Dividen (Studi Kasus Pada Perusahaan Manufaktur Sektor Otomotif dan Komponen yang Terdaftar di Bursa Efek Indonesia Periode 2011-2013). Universitas Komputer Indonesia.

Oktary, Dewi. 2017. Analisis Pengaruh Price Earning Ratio (PER), Current Ratio (CR), Debt to Equity Ratio (DER), dan Total Asset Turnover (TATO) Terhadap Return On Asset (ROA) pada Perusahaan Perbankan yang Terdaftar di Bursa Efek Indonesia Periode 2010-2012. Integra, Vol. 7, No 1, Januari 2017.

Perpatih, Zuhafini ST. 2016. Pengaruh ROA dan DER Terhadap Dividend Payout Ratio (DPR) pada Perusahaan Manufaktur Sektor Industri Dasar dan Kimia yang Terdaftar di Bursa Efek Indonesia. Jurnal Ekonomi STIE Pasaman.

Prasetyo, Ery Teguh. 2017. Debt to Equity Ratio dan Return On Asset Pengaruhnya Terhadap Dividend Payout Ratio (Studi Kasus Perusahaan Manufaktur di BEI Periode 2008-2011). Jurnal Kajian Ilmiah Universitas Bhayangkara Jakarta Raya, Vol. 17, No. 3. ISSN: 1410-9794. EISSN: 2597-792X. 
Rudianto. 2012. Pengantar Akuntansi Konsep \& Teknik Penyusunan Laporan Keuangan. Jakarta: Erlangga.

Sartono, Agus. 2010. Manajemen Keuangan Teori dan Aplikasi. Edisi Keempat. Yogyakarta: BPFE.

Sholihin, Mahfud dan Dwi Ratmono. 2013. Analisis SEM-PLS dengan WarpPLS 3.0. Yogyakarta: ANDI OFFSET.

Sudana, I Made. 2011. Manajemen Keuangan Perusahaan Teori dan Praktek. Jakarta: Erlangga.

Sutrisno. 2012. Manajemen Keuangan Teori Konsep dan Aplikasi. Yogyakarta: Ekonisia. 